\title{
ПРАВО ГРОМАДЯН НА ОТРИМАННЯ БЕЗОПЛАТНОӤ ПРАВОВОї ДОПОМОГИ
}

\begin{abstract}
БОРТНИК Надія Петрівна - доктор юридичних наук, професор, завідувач кафедри адміністративного та інформаційного права Національного університету «Львівська політехніка»

ДМИТРИК Юрій Іванович - кандидат юридичних наук, доцент, доцент кафедри адміністративного та інформаційного права Національного університету «Львівська політехніка», УДК 342:347.921.8(045)
\end{abstract}

DOI 10.32782/EP.2020.3.7

\footnotetext{
В статье исследуются теоретико-правовъге основы бесплатной профессиональной юридической помощи. Анализируются на основании билособско-мировозренческих, общзенаучных и специальных методов взгляды ученых на понятие и сущность профессиональной юридической помощи. Рассмотренъг понятие и сущность профессиональной юридической помоши. Сделан въвод о том, что бесплатная правовая помощь - это правовая помощь, которая гарантируется государством и полностью или частично предоставляется за счет средств Государственного бюджета Украинъ, местных бюджетов и других источников, направленная на обеспечение реализации прав и свобод человека и гражданина, защить этих прав и свобод, восстановления в случае нарушения. Рассмотренъ организачионнъле и правовъле мерь обеспечения государством соблюдения приниипов предоставления бесплатной правовой помощи. Право на получение профессиональной правовой помощи раскрыто как многоаспектное право, которое вылтуппет как самостоятельное и комплексное конституиионное право, не подлежит ограничению, но одновременно не является абсолютным правом.

Ключевъе слова: правовая помошь, бесплатная правовая помощь, первичная и вторичная правовая помощь, субъекть получения и предоставления бесплатной правовой помощи.
}

\section{Постановка проблеми}

Конституція України визначила пріоритет особи, ії̈ прав і свобод. Це твердження є одним з основоположних для розвитку правової системи в Україні. Права та свободи громадян, закріплені в Конституції, матимуть дієве значення лише при наявності правового механізму реалізації. Стаття 59 Конституції гарантує кожному громадянину право на отримання професійної правничої допомоги. Це положення обумовлює необхідність однакового юридичного захисту всіх громадян, які потребують такої допомоги, незалежно від матеріального статусу. Інакше буде порушено рівність громадян і принцип гарантії чесного ведення процесу. Поняття «правнича допомога» $\mathrm{i}$ «безоплатна правнича допомога» законодавством не закріплені. Немає єдиного розуміння, яку правничу допомогу необхідно вважати професійною.

Аналіз дослідження проблеми

Дослідженням питань надання безоплатної правової допомоги займалося багато науковців, зокрема: О. М. Бандурка, Ю. П. Битяк, О. Г. Гамалій, А. М. Колодій, А. Т. Комзюк, В. П. Пєтков, Ю. І. Руснак, О. Ф. Скакун, С. Г. Стеценко, Ю. М. Тодика, В. І. Форманюк, Ю. С. Шемшученко, Ю. Т. Шрамко та інші. Однак, незважаючи на широкий спектр досліджень, присвячених різним аспектам надання безоплатної 
правової допомоги, існує низка питань, що залишаються дискусійними.

Мета статті - дослідження права громадян на отримання безоплатної правової допомоги.

\section{Виклад основного матеріалу}

Право на отримання безоплатної правової допомоги необхідно розглядати як складову прав людини. Права людини - це невід'ємна частина суспільних відносин, вони є правовою формою взаємозв'язку між членами суспільства, координації поведінки та вчинків людей. Право на отримання безоплатної правової допомоги належить до такого виду прав людини, як права-гарантії. В основі ці права формулюють умови та можливості людей, які об'єктивно необхідні для забезпечення нормального функціонування індивіда, суспільства, держави.

Гарантоване Конституцією право на професійну допомогу необхідно розглядати як запобіжне володіння людиною певного соціального блага, можливості отримання професійного сприяння у відстоюванні прав і законних інтересів адвокатурою, нотаріатом та іншими організаціями.

Будучи конституційним правом на отримання професійної правової допомоги, що закріплене ст. 59 Конституції України відповідно до міжнародних норм і принципів, воно є реальною гарантією кожної людини бути забезпеченою захистом порушених прав, свобод і законних інтересів [1].

О. М. Макеєва та В. В. Бурбеза мають на увазі не тільки вже порушені права, свободи та законні інтереси, а й ті, що знаходяться під загрозою порушення. Такий захист здійснюється суб'єктами, що володіють повноваженнями надавати кваліфіковану правову допомогу. Згідно 3 п. 3 ч. 1 статті 1 Закону України «Про безоплатну правову допомогу», правова допомога - це надання правових послуг, спрямованих на забезпечення реалізації прав і свобод людини і громадянина, захисту цих прав і свобод, їх відновлення у разі порушення $[2$, с. $126 ; 2]$.
Основні права і свободи людини та громадянина $\epsilon$ невідчужуваними, належать кожному від народження, право на отримання професійної правової допомоги, в тому числі допомоги безоплатної, обмеженню не підлягає.

Більшість дослідників виділяє такі елементи права на отримання правової допомоги, як правова допомога при забезпеченні прав і свобод особи, правова допомога при захисті, при формуванні правосвідомості.

При розробці закону однією 3 головних цілей було визначено необхідність створення умов для реалізації встановленого Конституцією права громадян на отримання професійної правової допомоги.

У Законі України «Про безоплатну правову допомогу» закріплено право на отримання професійної правової допомоги, визначено, що випадки та порядок надання такої допомоги повинні бути врегульовані законом. Фактично ця стаття дублює зміст Конституції, в якій закріплено, що тільки у випадках, передбачених законом, правова допомога надається безоплатно.

Законодавчо визначено, що єдиним видом нормативно-правового акта, що закріплює випадки надання правової допомоги, є закон.

Закон України «Про безоплатну правову допомогу» визначає загальні вимоги до суб'єктів, які мають право на отримання правової допомоги безоплатно. На думку авторів науково-практичного коментаря під редакцією В. М. Онищука, необхідно виходити з того, що розглядається лише потенційне право відповідної категорії громадян, які мають право отримати безоплатну правову допомогу [3, с.22]. Хоча органи і організації, що входять у державну та недержавну системи надання такої допомоги, зобов'язані надати їі безоплатHo.

Пільговим категоріям громадян, які мають відповідне право, оплата наданих їм послуг здійснюється 3 Державного та місцевих бюджетів. Місцеві органи державної влади можуть розширювати та до- 
повнювати список пільговиків залежно від можливостей регіону.

За загальним правилом, установленим у ч. 1 ст. 3 Закону України «Про безоплатну правову допомогу», зазначається, що «Право на безоплатну правову допомогу - це гарантована Конституцією України можливість громадянина України, іноземця, особи без громадянства, у тому числі біженця чи особи, яка потребує додаткового захисту, отримати в повному обсязі безоплатну первинну правову допомогу, а також можливість певної категорії осіб отримати безоплатну вторинну правову допомогу у випадках, передбачених цим Законом» [4]. Право на безоплатну вторинну правову допомогу мають громадяни держав, з якими Україна уклала відповідні міжнародні договори про правову допомогу, згода на обов'язковість яких надана Верховною Радою України, а також іноземці та особи без громадянства відповідно до міжнародних договорів, учасником яких є Україна, якщо такі договори зобов'язують держав-учасниць надавати певним категоріям осіб безоплатну правову допомогу.

Водночас, Закон України «Про правовий статус іноземців і осіб без громадянства» грунтується на національному принципі закріплення правового статусу іноземців [5]. Іноземець, який перебуває на території України, має всі права і свободи, несе обов'язки, якими наділені громадяни України, за винятком випадків, прямо встановлених зазначеним Законом.

Розглянемо можливості надання безоплатної правової допомоги іноземним громадянам i особам без громадянства. Законом і відповідним міжнародним договором повинні бути визначені, в яких випадках іноземні громадяни та особи без громадянства можуть отримати безоплатну правову допомогу, а також порядок іï отримання.

На думку С. М. Бреус, законодавець не обмежився гарантуванням надання безоплатної вторинної професійної правничої допомоги лише громадянам України, розширивши його до осіб, які перебувають під юрисдикцією України [6, с. 33].
Виходячи із зазначеного, іноземні громадяни або особи без громадянства, які живуть, працюють, отримують освіту в Україні, можуть отримати правову допомогу безоплатно у випадках, пов'язаних 3 кримінальним провадженням. Така ж можливість повинна виникати, якщо такі особи виступають відповідачами у цивільній справі та проходять військову службу за контрактом.

Сьогодні міжнародне співробітництво 3 питання безоплатного надання іноземним громадянам правової допомоги зводиться до підписання регіональних угод і двосторонніх міжнародних договорів, які є типовими. Тим іноземним громадянам, які тимчасово проживають на території України, правову допомогу повинні надавати консульські установи тієї держави, громадянами якої вони $\epsilon$, на тих умовах, які встановлені національним законодавством. Громадянам України, які перебувають на території іноземних держав, первинну правову допомогу консульські установи надають безоплатно.

Натомість, вважаємо, що зовсім поіншому виглядає справа з іноземцями, які постійно проживають в Україні та реалізовують свої права на певні трудові відносини. Такі особи повинні набути право на правову допомогу, гарантовану ст. 59 Конституції України. Питання про умови, при яких вона повинна бути надана, сьогодні залишається відкритим. Безоплатна допомога може бути надана малозабезпеченому іноземцю. Для деяких категорій іноземних громадян із загального правила можливі виключення. Так, ст. 13 Закону України «Про біженців та осіб, які потребують додаткового або тимчасового захисту» прямо наділяе особу, яка визнана біженцем правом на безоплатну правову допомогу у встановленому порядку [7].

На нашу думку, основними характеристиками права на отримання правової допомоги є: конституційне право на правову допомогу в суб'єктивному і об'єктивному значеннях; невід'ємність і неможливість обмеження права на правову допомогу; конституційне право на правову допомогу є основним правом людини; реалізація 
стративне право

права на правову допомогу базується на принципах конституційного статусу людини; конституційне право на правову допомогу має всі ознаки конституційних прав людини і громадянина; правова природа права на кваліфіковану правову допомогу.

Конституційне право на отримання професійної правової допомоги є суб'єктивним правом тому, що дозволяє отримувати кожному певні блага. У цьому випадку благом буде виступати правова допомога, в тому числі безоплатна.

Конституційне право на отримання професійної правової допомоги не може бути обмежене, у тому випадку, коли йдеться про можливе порушення державної таємниці.

Угода про асоціацію між Україною, 3 одного боку, та Европейським Союзом, Европейським співтовариством 3 атомної енергії і їхніми державами-членами, 3 іншого боку, внесла зміни у всі сфери життя держави та суспільства [8]. Це спричинило необхідність на законодавчому рівні формування та забезпечення безперебійного функціонування державної системи безоплатної правової допомоги.

Фактично держава вперше в новітній історії України дала змогу громадянам реалізувати надане Конституцією право на отримання професійної правової допомоги не на словах, а на ділі, взяла відповідальність за створення державної системи безоплатної правової допомоги. Це стало передумовою створення додаткових державних гарантій у сфері надання та отримання професійної правової допомоги.

Держава не може обмежити право громадянина на отримання професійної правової допомоги. Згідно 3 Конституцією права і свободи людини та громадянина можуть бути обмежені законом тільки в тій мірі, в якій це необхідно з метою захисту основ конституційного ладу, моральності, здоров'я, прав і законних інтересів інших осіб, забезпечення оборони країни та безпеки держави. 3 логіки статті 64 Конституції можна зробити висновок, що використання права на отримання правової допомоги не становить ніякої загрози основам конституційного ладу та безпеки громадян і не може 3 цієї причини бути обмеженим державою.

Тому згідно з Конституцією право на отримання професійної правової допомоги віднесено до тих конституційних прав i свобод, які не підлягають обмеженню. Хоча це право не підлягає обмеженню навіть в умовах надзвичайного стану, проте воно не $є$ абсолютним. Однак, деякі дослідники вважають це право абсолютним. Попри те в Конституції закріплено, що здійснення прав і свобод людини та громадянина не повинно порушувати прав i свобод інших осіб.

Право на отримання правової допомоги має межі здійснення, не може бути використано 3 метою заподіяння шкоди правам і законним інтересам інших осіб. Хоча Конституція закріплює, що права i свободи людини та громадянина є найвищою цінністю, а визнання, дотримання i захист прав і свобод - це обов'язок держави, проте здійснення прав і свобод людини та громадянина не повинно порушувати права та свободи інших осіб.

Права і свободи людини та громадянина є безпосередньо дієвими. В Україні не повинні видаватися закони, що скасовують або применшують права і свободи людини та громадянина. Ці положення відносно права на отримання професійної правової допомоги можна трактувати так: визнання, дотримання та захист права на правову допомогу закріплюється як обов'язок держави, оскільки має конституційний статус; права і свободи інших осіб при здійсненні права на професійну правову допомогу не повинні порушуватися. Конституційне право на правову допомогу не є абсолютним, не може використовуватися на шкоду і має межі, які визначаються правами і законними інтересами інших осіб; право на отримання професійної правової допомоги є безпосередньо дієвим; в Україні не повинні видаватися закони, що скасовують або ущемляють право на правову допомогу.

У Конституції чітко проглядається закріплення норм, спрямованих на забезпечення захисту прав і свобод громадян. 
Такий захист багато в чому визначається змогою забезпечення правової допомоги. Однією зі складових конституційно-правового механізму забезпечення основних прав людини в Україні є механізм забезпечення людини кваліфікованою юридичною допомогою. Це взята в єдності система правових засобів, через яку здійснюється юридичне сприяння людині в правоохоронних або правозахисних відносинах $з$ приводу реалізації основних прав. До зазначеної системи доцільно віднести права-гарантії людини та громадянина: на державний захист прав; право захищати права і свободи всіма способами; право на судовий захист прав і свобод; право на отримання професійної правової допомоги; право користуватися допомогою адвоката; право не свідчити проти себе та близьких родичів; право на компенсацію заподіяної шкоди від злочину і зловживання владою; презумпцію невинуватості.

У літературі є спроби дати визначення права на отримання професійної правової допомоги. Так, С. В. Устюшенко зазначає, що різниця між поняттями «правова допомога» та «правнича допомога» полягає в тому, що в назві «правова допомога» відображено коло питань, у яких надається допомога, тобто допомога у питаннях права, тоді як у категорії «правнича допомога» акцент робиться на суб'єкті її надання, тобто це допомога, надана правником. Таке зміщення акцентів у назві покликане зайвий раз підкреслити, що допомога 3 правових питань має надаватися лише фахівцем, особою правничої професії [9, с. 28].

Автори колективної монографії «Право особи на безоплатну правову допомогу» зазначають, що право на безоплатну правову допомогу - вид державної гарантії щодо реалізації та захисту прав і законних інтересів людини, що здійснюється шляхом надання правової допомоги визначеним у законодавстві категоріям населення в порядку і на підставах, передбачених законом, за рахунок бюджетних коштів [10, c. 51$]$.

На нашу думку, розглянуті вище визначення не зачіпають таких елементів права громадян на отримання правової допомоги, як право на правову допомогу для формування правосвідомості, право на отримання юридичної інформації, право на роз'яснення змісту правових норм, право на отримання юридичних знань 3 метою підвищення правової культури. 3 наведених суджень також не випливає право на представництво в рамках цивільних та адміністративних правовідносин.

Право на отримання професійної правової допомоги можна розглядати як закріплену Конституцією відповідно до міжнародних норм і принципів можливість кожного, по-перше, отримувати певні блага; по-друге, захищати реально порушені права, свободи та законні інтереси; по-третє, захищати права, свободи та законні інтереси, що знаходяться під загрозою. Але для надання допомоги необхідно звертатися до спеціальних суб'єктів.

Право на отримання професійної правової допомоги для громадян - це реалізація цілого спектру повноважень різних державних органів, пов'язаних з організацією та здійсненням цієї допомоги, контролем за якістю її надання. Подібні повноваження притаманні органам виконавчої влади, на які покладено значну кількість організаційно-правових питань виконавчого та розпорядчого характеру в цій сфеpi, певні управлінські дії.

У Законі України «Про безоплатну правову допомогу» виділено три групи правовідносин у цій сфері. Перша група - це відносини, що встановлюють основні гарантій реалізації права громадян на отримання безоплатної професійної правової допомоги, спеціальні норми, що захищають і забезпечують права громадян, встановлені ст. 59 Конституції України.

Друга група правовідносин пов'язана зі встановленням організаційно-правових основ формування державної та недержавної систем безоплатної правової допомоги. Третя група правовідносин регулює діяльність 3 правового інформування i правової освіти населення. Ця група правовідносин дуже важлива, адже розвиток правової держави, формування громадянської правосвідомості, вирішення проблеми правового нігілізму в Україні вимага- 
ють підвищення рівня правової культури, без якої неможливо повною мірою реалізувати такі цінності в житті суспільства, як пріоритет прав і свобод людини, верховенство закону, гарантія захисту публічних інтересів.

Варто зазначити, що законодавство, яке регулює надання професійної, в тому числі безоплатної правової допомоги громадянам, містить й інші групи правовідносин у вказаній сфері.

\section{Висновки}

Підсумовуючи викладене вище, можемо зробити висновок про те, що право на отримання професійної правової допомоги, розкриваючи зміст правового характеру держави, виступає як самостійне та комплексне права, що не підлягає обмеженню, забезпечує правові гарантії та способи реалізації та захисту інших конституційних прав і свобод людини та громадянина, є похідним від конституційних прав на інформацію, на державний захист прав і свобод, на охорону державою гідності особи, є механізм опосередкування відносин і зв'язків між суспільством, державою та громадянином, що реалізується в найбільш важливих сферах суспільного життя, забезпечуючи надання певних благ.

Особливістю права на отримання професійної правової допомоги є те, що воно опосередковує відносини та зв'язки громадян між собою та 3 державою; має інтегральний характер, у структуру якого включені: право звернутися за професійною правовою допомогою до різних суб'єктів їі надання з метою ефективного здійснення та захисту прав, свобод і законних інтересів; право на певний зміст i якість наданої правової допомоги; право на отримання професійної правової допомоги безоплатно у передбачених законом випадках; право вимоги вчинення певних активних і ефективних дій відповідного суб'єкта надання правової допомоги; право на отримання інформації про можливості отримання професійної правової допомоги, в тому числі безоплатно; право на отримання професійної правової до- помоги на мові споживача та зручній для споживача допомоги формі; право вимоги захисту порушеного права.

\section{Аітература}

1. Конституція України: Закон України від 28.06.1996 р. № 254к/96-ВР. Відомості Верховной Ради Украӥни. 1996. № 30. Ciт. 141.

2. Макеєва О. М., Бурбеза В. В. Безоплатна правова допомога: теоретико-правові засади. Юридичний вісник. 2018. № 3 (48). С. 124-130.

3. Оніщук М. В. Закон України «Про безоплатну правову допомогу»: науковопрактичний коментар / О. І. Клименко та ін.; за заг. ред. М. В. Оніщука. Київ: КПСервic, 2012. 100 c.

4. Про безоплатну правову допомогу: Закон України від 02.06.2011 р. № 3460VI. Відомості Верховної Ради Украӥни. 2011. № 51 . C. 577.

5. Про правовий статус іноземців і осіб без громадянства: Закон України від 22.09.2011 р. № 3773-VI. Відомості Верховной Ради Украйни. 2012. № 19-20. Ст. 179.

6. Бреус С. М. Суб'єкти права на безоплатну професійну правничу допомогу. Науковий вісник Національної академії внутрішніх справ. 2017. № 1 (102). С. 30-39.

7. Про біженців та осіб, які потребують додаткового або тимчасового захисту: Закон України від 08.07.2011 p. № 3671-VI. Відомості Верховної Ради України. 2012.№ 16 . Ст. 146.

8. Про ратифікацію Угоди про асоціацію між Україною, з однієї сторони, та Европейським Союзом, Европейським співтовариством 3 атомної енергії і їхніми державами-членами, з іншої сторони: Закон України від 16.09.2014 р. № 1678-VII. Відомості Верховної Ради України. 2014.№ 40. Ст. 2021.

9. Устюшенко С. Витрати на професійну правничу допомогу в цивільному судочинстві. Підприємництво, господарство $i$ право. 2019. № 9. С. 27-31.

10. Данилевська Ю. О., Павлик А. В., Петрович 3. З., Цмоць У. О. Право особи на безоплатну правову допомогу. Аьвів: АьвДУВС, 2018. 136 с. 


\section{АНОТАЦІЯ}

у статті досліджуються теоретико-правові засади безоплатної професійної правової допомоги. Аналізуються на підставі філософсъко-світоглядних, загальнонаукових та спеціальних методів погляди вчених на поняття та сутність професійної безоплатной правовой допомоги. Розглянуто поняття та сутність профбесійної безоплатної правової допомоги. Зроблено висновок про те, що безоплатна правова допомога - це правова допомога, яка гарантується державою та повністю або частково надається за рахунок коштів Державного бюджету Украӥни, місцевих бюджетів та інших джерел, спрямована на забезпечення реалізачиі прав і свобод людини та громадянина, захисту цих прав і свобод, відновлення у разі порушення. Розглянуто організаиійні та правові заходи забезпечення державою дотримання принициів надання безоплатної правової допомоги. Права на отримання професійной правової допомоги розкрито як багатоаспектне права, що виступає, як самостійне та комплексне конституиійне право, що не підлягає обмеженню, водночас, не є абсолютним правом.

Ключові слова: правова допомога, безоплатна правова допомога, первинна та вторинна правова допомога, суб'єкти отримання та надання безоплатної правової допомоги.
The article examines the theoretical and legal foundations of free professional legal aid. The views of scientists on the concept and essence of professional free legal aid are analyzed on the basis of philosophical and ideological, general scientific and special methods. The concept and essence of professional free legal aid are considered. It is concluded that free legal aid is legal aid guaranteed by the state and fully or partially provided by the State Budget of Ukraine, local budgets and other sources, aimed at ensuring the realization of human and civil rights and freedoms, protection of these rights and freedoms, recovery in case of violation. Organizational and legal measures to ensure the state's compliance with the principles of free legal aid are considered. The right to receive professional legal assistance is disclosed as a multifaceted right that acts as an independent and comprehensive constitutional right, which is not subject to restriction but is not an absolute right. The peculiarity of the right to receive professional legal assistance is that it mediates the relations and connections of citizens; has an integral character in the structure of which includes: the right to apply for professional legal assistance to various entities; the right to a certain content and quality of legal aid provided; the right to receive professional legal assistance free of charge in cases provided by law; the right to receive information on the possibilities of obtaining professional legal assistance, including free of charge; the right to receive professional legal assistance in the language of the consumer and in a form convenient for the consumer; the right to demand protection of the violated right.

Key words: legal aid, free legal aid, primary and secondary legal aid, subjects of receiving and providing free legal aid. 